\title{
Modern Dance Before The Three Generation Of Dancers On The Thought Yutong Shan ${ }^{1, a}$ \\ ${ }^{1}$ School of music and dance, Qujing Normal University, Yunnan, 655011 \\ ${ }^{a}$ email
}

\author{
Keywords: Modern dance; Classical ballet; Dance; Dance concept
}

\begin{abstract}
Modern dance is the 19th century at the end of the 20th century was born in the United States and Germany a dance revolution is opposed to classical ballet rigid closed under the premise of historical phenomenon. Modern dance in the development process, due to the artistic ideas and creation style, value orientation differences between the different styles and schools. For example, Martha - gram "contraction and relax" principle, Doris Humphrey "fell on the ground, climb up the dance training system in the future modern dance development provides a rare reference value. Modern dance dancers dance action however, free to express their true feelings. It is dance system

to inject fresh blood.To the dance to give a new meaning, in the history of dance has a pivotal position.
\end{abstract}

\section{The first generation of modern dance dancer thought}

The development of modern dance in American history, the most important representative is the "mother of the modern dance" reputation of the Isadora Duncan.1877 was born in San Francisco, 1927. She died in nice childhood love to dance, and also teach students Zibianziyan, because she had never received any formal dance training at that time. Duncan did not deliberately to create any new dance genre, she thinks the ballet violated the laws of nature, a ballet dancer should take off the toe shoes, pulling off their bras, the flesh and the spirit that the dancers are free, then you can according to their own way of free love to dance. During this period of modern dance view, that form follows function values to reveal people's value and dignity, reveal the spirit of the times and the reality of life. In the artistic creation, the feelings in the sense of form Now as the ability of art creation. In the ideological and artistic propositions reflect the real world, not only reflects the human nature good, also expose human evil. In the exploration, pay attention to personal style. Modern dance one of the biggest characteristics is to ask the dancer free liberation. It is the most important value is allows a choreographer home development and the performance of individual of his art, without the need to consider the original existing form and traditional.

Duncan is sympathetic to ballet dance students, she thinks learning ballet is torture practice. Because she thinks it all with the establishment of her school theory is completely. According to her theory draw further apart, the body to become transparent, showing the heart and spirit means. Isadora Duncan asked her students in the classroom can not imitate her, who she learned like, who is not well. "The period [1] Isadora Duncan is the first to fight a lone battle period for the development of the whole history of modern dance, she initiated the Western Dance Revolution from concept and method, and change the world dance appearance, so the" mother of the modern dance "reputation she gets.

Ruth St. Denise was born in 1877 in New Jersey, 1968 died in Los Angeles. St. Denise natural beauty of appearance, limb soft prompted her began in New York music hall song and dance drama, until she saw a cigarette advertising - Egypt reproductive goddess Aixisi, began to walk on the Zibianziyan road. Her life has created dance a lot of exoticism, in many countries in the East and West tour and caused a great sensation.

Ted Sean was born in 1891 in Kansas City, 1972 passed to the city of Orlando. He so loves to dance is actually a chance, if it wasn't for him because of leg disease and must learn dance therapy, perhaps his life also not to contact dance in 1914 the encounter the Ruth St. Denise and and the knot is husband and wife. He and Duncan, worship Tiancheng natural creation and natural beauty, while the body is the United States to the United States."Great American Dance" first lady of Ruth St. Denise and the American dance 
education "father Ted Sean couple in 1915 opened a" Denise Sean "dance school in Losangeles. This dance school courses are very diverse, not only from a Denise oriental dance and modern dance, Japanese dance American, Spanish dance, folk dance, and even classical ballet. The idea and method of" cross culture "was hit by half a century of neglect, but is now becoming an important course in American universities. From the historical point of view, we can easily understand how to American modern dance today, in the world to obtain an unstoppable force - from the beginning it is built on the foundation of large cosmopolitan cultures, and now the so-called is essentially a trend which cannot be halted, it will Some on the basis of traditional culture to create a new sent back into the world bale. "[2] we can't simple to it look to make an ordinary school of dance, it has nurtured the heroes of many American modern dance, including - Martha Graham, Doris Humphrey, check - Charles Weidman, and their descendants also to all over the world.

Rudolf Von Laban is Hungarian, some of his theory with Jacques Dalcroze teaching, the most important is through the Denise Shawn school, heritage to numerous dance later, laid the foundation for the quantitative methods of the theory and practice of modern

dance.

\section{The second generation of modern dance dancer thought}

Martha Graham was born in 1894 in Allegheny, 1991 died in New York. She was known as "one of the giants of 20th century art". Then why gram can get so high reputation? It is because she in Denise Shawn disciple many physiological life and art life is the longest, largest number of works, and she in her life, she also launched a different from the technical system of Humphrey and her system until now. So Graeme can well deserved sit tight in the 20th century art one of the giants of the throne.

In the summer of 1938,, founder of the New York Dance archive Jennievi also Fu - Mrs Oswald's visit to China, she with a video for Beijing Dance community broadcast modern dancer Martha Graham's training system and the representative of the repertoire, make Chinese dancers first experience to the western modern dance in the two aspects of body and soul shocking.

Martha Graeme's life the most important achievement is that she invented the "contraction and relaxation" dance training system, it has become a modern dance technique. Classical system emphasizes the dancer under the action of gravity, with the breath as the driving force, accompanied by breathing, on the spine of the drive, embodies the "principle of contraction relax. The main idea in revealing the dark human heart, emphasizing" introspection "psychology. She stressed the dancer should be" body image and self performance objective "beliefs", "dance should cover those peel human behavior" coat ", revealing an inner man". This training method, the dancer the back is strong and tough, greatly improving the performance of the action itself. This set of training still reflect the teaching of colleges and universities in the implementation of the training system obviously knows Graeme has so far An important position.

Doris Humphrey was born in 1895 in Illinois in accordance with the state of Oak Park, 1958, died in New York City.1917 years into "Denise Sean" dance school learning to dance, until 1928 with the same group of dancers Charles Weidman a separate, then two people together in New York established his own dance school and dance.

For art, artists and reality, Humphrey said: "I believe dancers belong to his age and area." "essential qualities of works of art, is a stick to the ideas of the era." she realized, various folk dance is a result of the formation of different nationalities in long-term traditional culture, it could not by another nation to copy, which she thinks her teacher Denise art limitations.

Doris Han Fuli created his "ground - up" dance training system, her dance skills center is driven by the imbalance of breathing and complex balance. She thinks it not only contains the full range of human action, it is the root of all the people in the dramatic effect. Such as violence down before they must support. Resistance, this conflict exists in these actions. And her system through its disciples - Lin Meng Huo plug has been spread and development. The technology system has affected Han Beverly freely in a modern dance show to see. Her choreography ideas through your focus "dance art $>$ to posterity, and this 
book has become an indispensable reference book for future generations. Professor director of Dance Courses.

Charles Weidman 1901 was born in Lincoln, Nebraska, USA, 1975 died in New York. He and Humphrey jointly run dance due to Humphrey's illness, so in 1945 the troupe announced their break-up. In the same year. Weidman another built his own dance school, 1948, in dance school based on established their dance.

A lot of people may not understand modern dance exactly in expressions, is, there are many dancers, although in modern dance, but they don't know they jump dancing in the end is what meaning, for this problem. Weidman in pantomime were resolved. He dances with strong mime ingredients. Weidman reason that preference for the pantomime dance is that he found that dancer's talent and theatre actor can actually in essence is consistent.

Performance at this point, I very much agree with weideman's view, he called "pantomime" is not to speak, nor without text speech story, but the thought and emotion into the action. Imagine if we didn't have feelings and emotions into the dance moves, then presented the dance works will is blank feebly, at least I think so.

\section{The third generation of modern dance dancer thought}

Seamus Cunningham was born in 1919 in Washington State Forest treglia 1939 started in, he joined the grammer's dance troupe, and starred in the gram four medium-term masterpiece. In the middle of the sixth generation descendant of the gram, the dance body aesthetics to make greatest contribution Mo too Kramers - Cunningham.

Cunningham's early dance creation is a "dramatic", but he believes that his "dramatic" is a relative term, a relative of the form, will undoubtedly have a dramatic. Cunningham dance "does not exhibit any feelings, not the slightest emotion and plot as the clue and rely on, not only did he abandon the dance narrative function, but also the negative emotional expression of dance." [3] he thinks, "dance is the origin of the action is in the space movement of the human body." he is only concerned with [10] is the "dance, dance" as the only content of the dance, and he also set up their own "pure dance" style. Cunningham "opportunity times dance" affected Chinese $<>$ Ching, sortilege enlightenment, choreography method for landing decision, he opposed the people always think "dance Must have the basic requirements of meaning ". He said:" in my dance art is contain no idea ". The art is the pursuit of" occasionally action. Any action can become a dance. He believes that human life is often used to bound, if you use my composition in choreography, may find the human instinct and the most attractive way of action. Cunningham composes the "chance choreography", American modern dance circles to cultivate a large number of eminent choreographer.

Paul Taylor was born in 1930 in Pennsylvania in the United States. In Allegheny grammer's six generation, the most popular is Paul Taylor. "As a director, Taylor not only high quality and rich productive imagination and sense of music, but also has a sense of humor, so the presentation of the work is also beautiful not a lack of strength, smooth and full of changes, sometimes easily like life, and sometimes tense like drama." [4] Paul Taylor said: "we do not lack of action, but found that for excellent service action [5] eyes." so he created dance works are different from "- Cunningham dance works. His creation of the changing style, so we can bring the audience happy, and finally entered the dance master in the ranks.

In the United States the most influential to the Juilliard School of music, the dance department of modern dance classes on the creation of the "Paul Taylor style technology" the curriculum, they think Paul Taylor tradition of modern dance technique has very much artistic value, it is worth serious students system to learn. From this you can see Paul Taylor composing system still has a pivotal position.

Joseph Meng Lin in 1908 was born in Sinaloa, Mexico, the state capital of Curia hom a music interest of family, 1972 died in New Jersey Farringdon. He is the successor of the modern dance master 
Humphrey disciple is one of the most important, he and continues the tradition of Humphrey "fell to the ground - up" dance training system to become one of the important genre of American modern dance technique system.

A modern dance, as a prominent statement of contemporary dancer Lin Meng don't think modern dance is a particular genre, he said: "the modern dance is a state of mind, an understanding of the necessity of dance art and time synchronization." at the same time, he also pointed out modern dance does not belong to the flow line art, it is belong to a serious art. This also led to the modern dance does not belong to popular, not fashionable more than pretty cheesy. But serious art is the spirit of our age.

Lin Meng in their own dance art construction, inherited and developed the first generation of artists of the humanitarian tradition and humanistic spirit, and thus formed his own dance artistic features. Lin Meng skills training based on the principle of Han Furui technique, and then injected into the forest Mongolia personal research experience, according to various parts of the body as a single instrument. When the body moves, like a symphony, a variety of musical instruments playing together melody. Lin Meng remember his teacher Han Fuli, "human" is the most suitable for a choreography theme, theme concept of this view has become Lin dream of "humanism", but also the identity Graeme view, people passion, sin and noble can become a great dance.

\section{Conclusion}

Some people think that modern dance is a movement, a kind of attitude or is a concept, although there are many different views on modern dance, of which is no doubt, is that it will continue to pursue the character of individuality and innovation consciousness is lead to still be able to give it an exact definition. A modern dance, as Dance Aesthetics of the assertion that "modern dancer, sober minded thinker and philosopher, and is no longer that can only imitate, but not to think about the creation of the artists or craftsmen, so ideological and philosophical is always one of the important characteristics of modern dance. To learn how to dance in dance as a modern dance circles in a "baby", its "birth" and "growth" is history can resist change, we should develop the vision to look at it, although it was denied, but in my opinion either before or after, the modern dance will be immortal development continues, and will become better and better. Now various colleges and universities have opened the "modern dance" the dance courses for students is very good opportunity, can be better to know to get to the bottom "modern dance", when we are really contact and understanding of the "modern dance" in the future, it will find it "beautiful" and "charm".

\section{References:}

[1] Lu Yisheng. The characteristics of the modern dance is not characteristic of [J]. dance, 1995, (01): 19-21.

[2] Long Yin Pei. The dance Knowledge Manual [M]. Shanghai: Shanghai music publishing house, 1999.396-397.

[3] Xiajing. Explore modern dance movements constitute the ideographic characteristics [J]. Nanjing University of the Arts Journal of music and performing version. 2011, (03): 152-157.

[4] Ou Jianping. History of foreign dance and appreciation of the works [M]. Beijing: Higher Education Press, 2008.194-195.

[5] Chen Chen of the development trend of the modern dance education and Inspiration of Beijing Dance Academy [J]. 2014, (02): 147-149. 